\title{
著明な聴力改善を認めたインフルエンザ菌䯣膜炎による 両側感音難聴症例
}

\author{
平井 良治, 鴫原俊太郎, 池田 稔 \\ 日本大学医学部耳鼻咽喉科学教室
}

\begin{abstract}
要旨：細菌性髄膜炎後の内耳障害は, 髄膜炎の後遺症として広く知られており, その予後 は不良であることも知られている。今回, 細菌性髄膜炎羅患後に高度難聴が生じ, その後 著明に改善を認めた症例を経験した。症例は， 3 歳 3 カ月の男児で, インフルエンザ菌 (BLNAR) による細菌性㕼膜炎の治療中に中等度から高度の感音性難聴および平衡機能障 害が生じた。抗生剤，ステロイド，グリセオール，メシル酸ガベキセートなどにより治療 を行ったところ, 約半年後には, 正常聴力まで改善した。本症例の聴力障害は, インフル エンザ菌による serous labyrinthitis によるものであったと推測した。
\end{abstract}

$$
\text { ーキーワードー }
$$

䯣膜炎後難聴，ステロイド，聴力改善

\section{はじめに}

後天性の聾の原因として細菌性䯑道膜炎は, 最も頻 度が高く, 細菌性䚛膜炎後の感音難聴は一般的に改 善がそしいとされる1)。また細菌性髄膜炎は, 内耳 の骨化を遅発性に引き起こすことがあるため, 人工 内耳などの後療法に臨床上問題を生じることもあ $\eta$, 近年問題視されている。今回 BLNAR（ $\beta$-lactamase negative ampicillin resistant) による細菌性 髄膜炎の治療中に中等度から高度の難聴が出現した が, その後著明な改善を認めた症例を経験したので 若干の文献的考察を含め報告する。

\section{症例}

3 歳 3 カ月の男児

主訴：難聴の疑い

家族歴，既往歴：特記すべきことなし。

現病歴: 平成15年 4 月 26 日より発熱を認め, 同年 4 月27日当院救急外来において小览科を受診した。 消炎酵素剂の処方を受けるも発熱の改善を認めず, さらに軽度の意識障害も出現したため翌 28 日, 再度
当院救急外来小児科を受診した。項部硬直，及び䯣 液検查にて細胞数 960 (好中球優位), 糖 $: 32 \mathrm{mg} / \mathrm{dl}$ を認め, 化膿性髄膜炎が疑われたため緊急入院とな った。抗生剤 (PAPM/BP, CTX, CTRX), デカド ロン $2 \mathrm{mg} \times 4 /$ day $\times 4$ 日間，グリセオール，FOY による治療を開始した。髄液細菌培養の結果, 起炎 菌はLow-BLNAR（PBP 3 変異）であった。小児科 にて施行した同月30日の右耳85dBnHLクリック音 の $\mathrm{ABR}$ (図 1) で波形を認めず，また 5 月 2 日施 行の MRI（図 2 ）で副鼻腔炎の存在が疑われたた め同日当科受診となった。

初診時現症: 雨鼓膜は発赤, 渗出液の野留を認め ず，粘性な鼻汁を両鼻腔に認めた。遊戯聴力検查， ティンパノメトリーを試みるも，啼泣のため施行で きなかった。

経過（図 3）：5 月 5 日ごろより音への反応がさ らに増悪した。 5 月 6 日のティンパノメトリーで左 $\mathrm{A}$ 型（ピークはー70daPa 程度）右 $\mathrm{A}$ 型（ピークー30 $\mathrm{daPa}$ 程度) であった。クリック音による $\mathrm{ABR}$ (図 4 ) にて, 右耳閾值 $90 \mathrm{dBnHL}$, 左耳閾值で80から70 dBnHLであった。DPOAEにて，DPレベルは両耳 

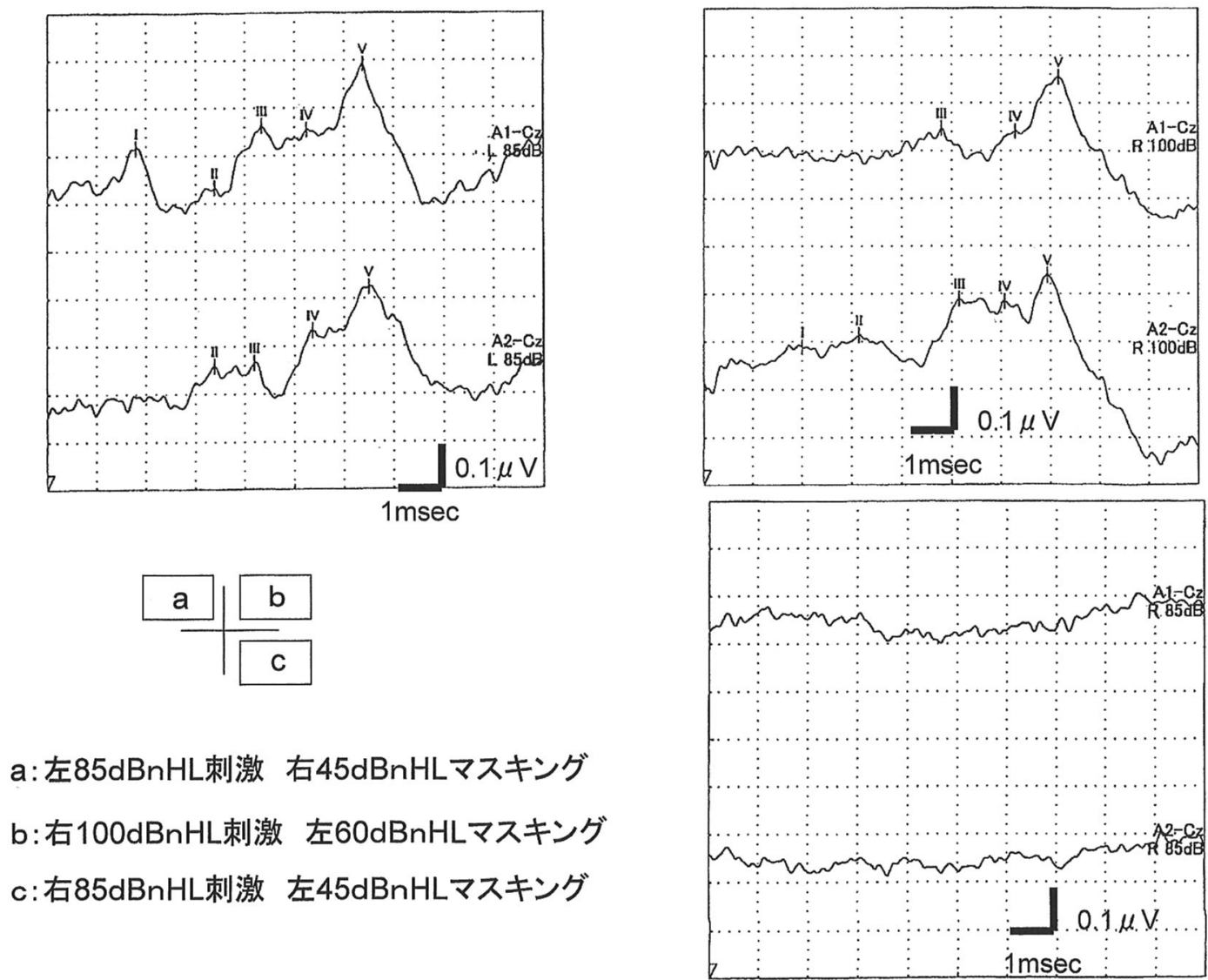

図14月30日に施行された $\mathrm{ABR}$

Midazolam を用い非覚醒状態で，脳波室にて施行。

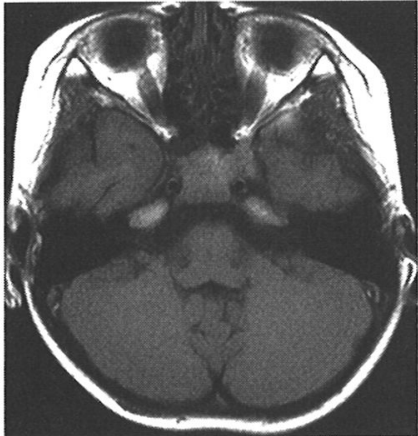

T 1

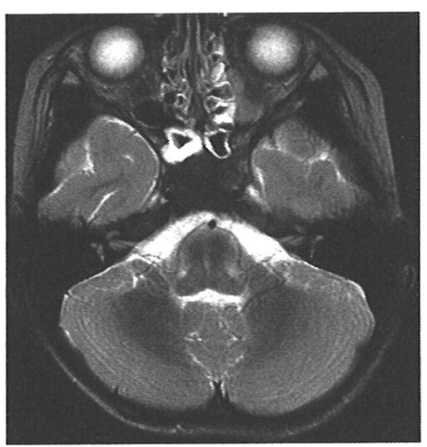

T 2

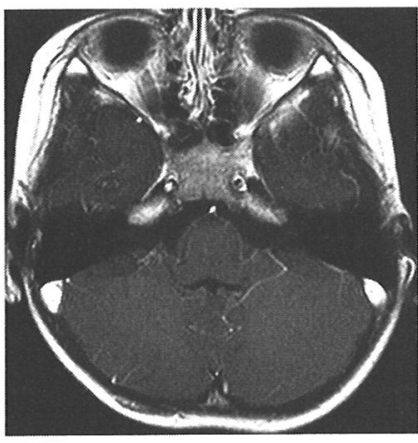

$\mathrm{T} 1 \mathrm{~Gb}$

図25月 2 日施行された後頭蓋 MRI 所見 両穊骨洞の粘膜肥厚を認める。

ノイズレベル以下で，両側感音難聴を認めた。 5 月 7 日の COR (conditioned orientation response test) (図 5 )で90から $100 \mathrm{~dB}$ の聴力閾值を認めた。 5 月 11 日頃全身状態の改善がみられ機嫌が良い時間が増え ている一方で, 単独立位不可, 歩行不可など平衡障 害を示唆する症状に小览科医が気付いたが，眼振は はっきりしなかった。5月13日の中耳 CT（図 6 ）
にて内耳奇形, 螖牛の骨化などの異常は認められな かった。 5 月15日より静注にてプレドニン $30 \mathrm{mg}$ か らの漸減投与を施行した。その後，5月24日施行の $\mathrm{COR}$ (図 7 ) で60dB まで聴力闒值の改善がみられ た。5月27日のクリック音によるABR（図 8 ）で は右耳60から70dBnHLまで, 左耳60から70dBnHL まで聴覚機能の改善がみられた。さらに 7 月 8 日の 


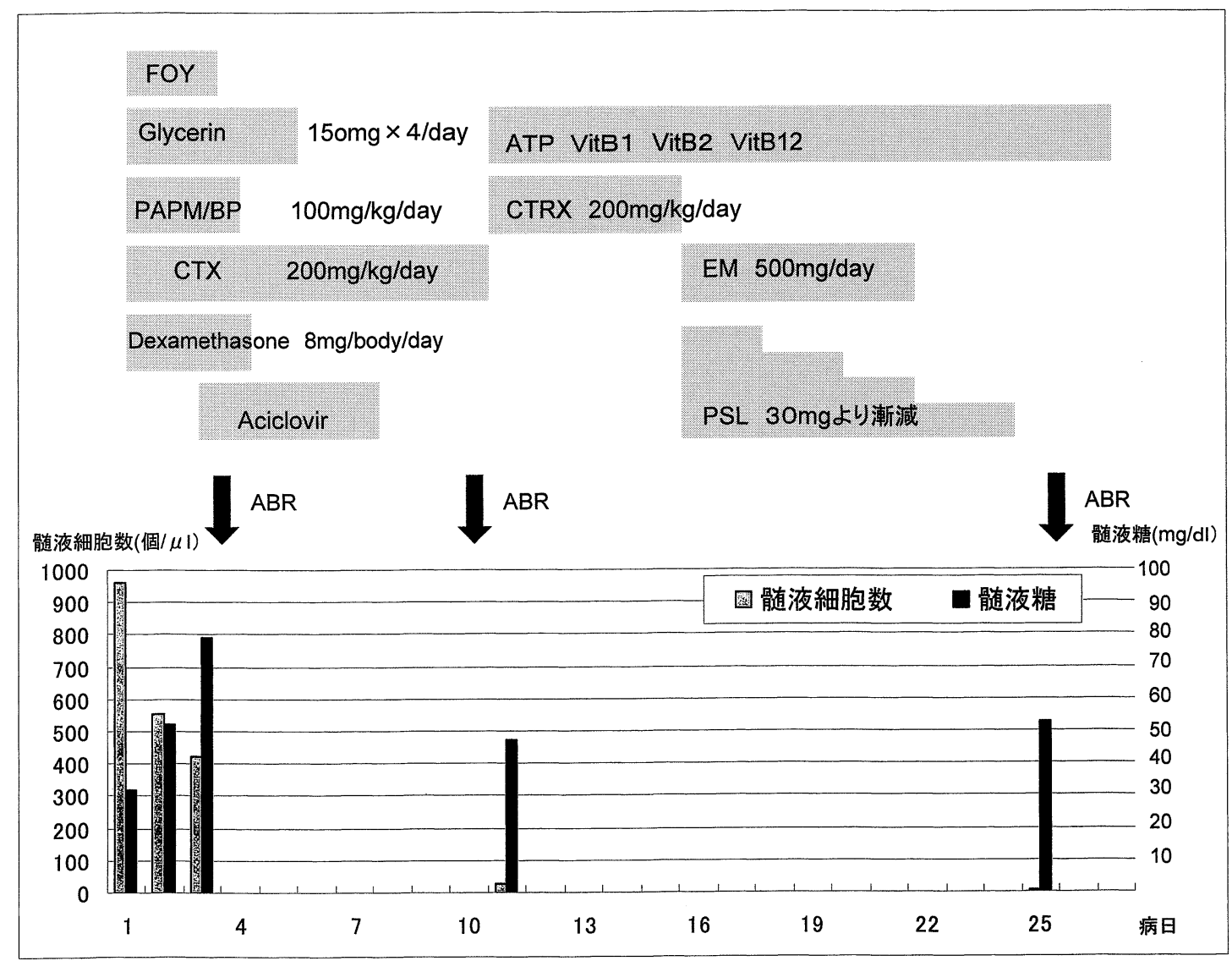

図 3 治療経過（䯣液中細胞数と髄液中糖濃度の変化も含む）

\section{左耳}

(dBnHL)

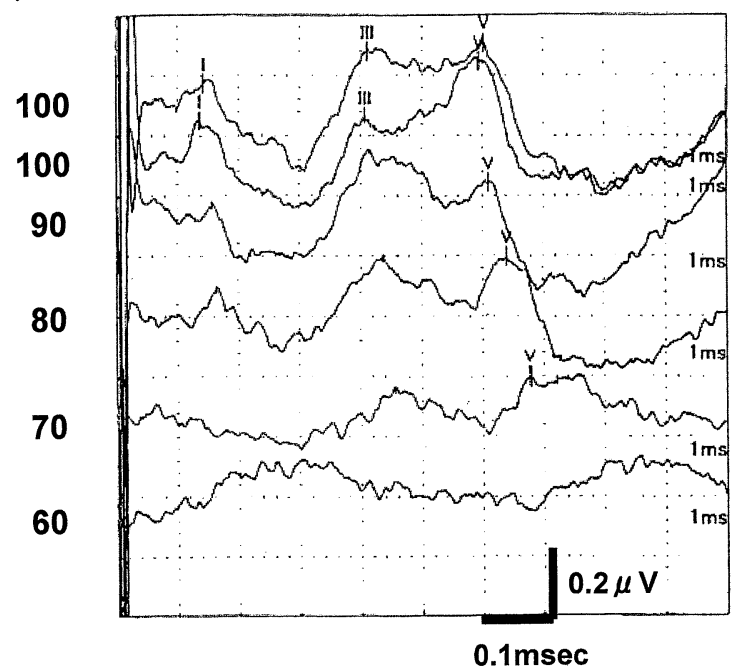

右耳

(dBnHL)

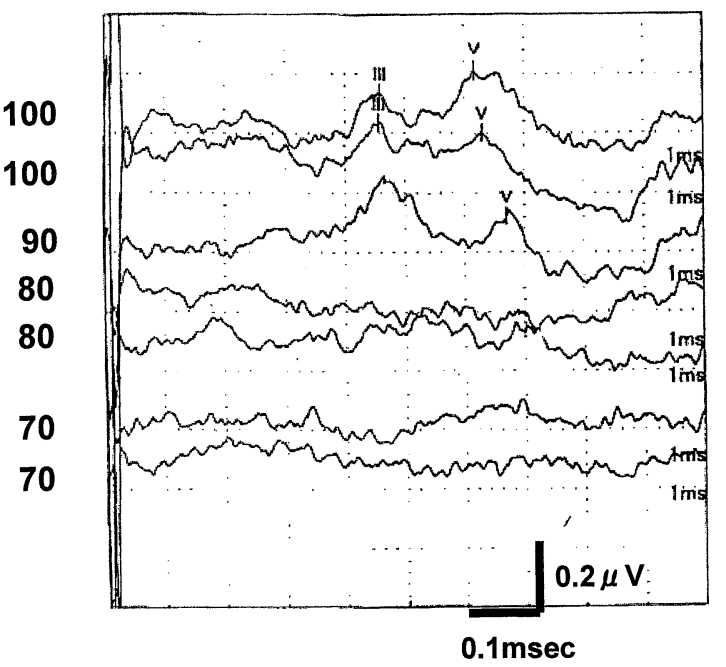

図45月 日に施行した $\mathrm{ABR}$

Triclofos sodium を用い非覚醒状態で，シールドルームで施行した。

標準純音聴力検査（図 9 a) で改善をみとめ，11月 18 日の純音聴力検查（図 $9 \mathrm{~b}$ ) では正常聴力にまで改 善を認めた。

\section{考察}

小児の細菌性䯣膜炎は，医療技術が発展した現在 


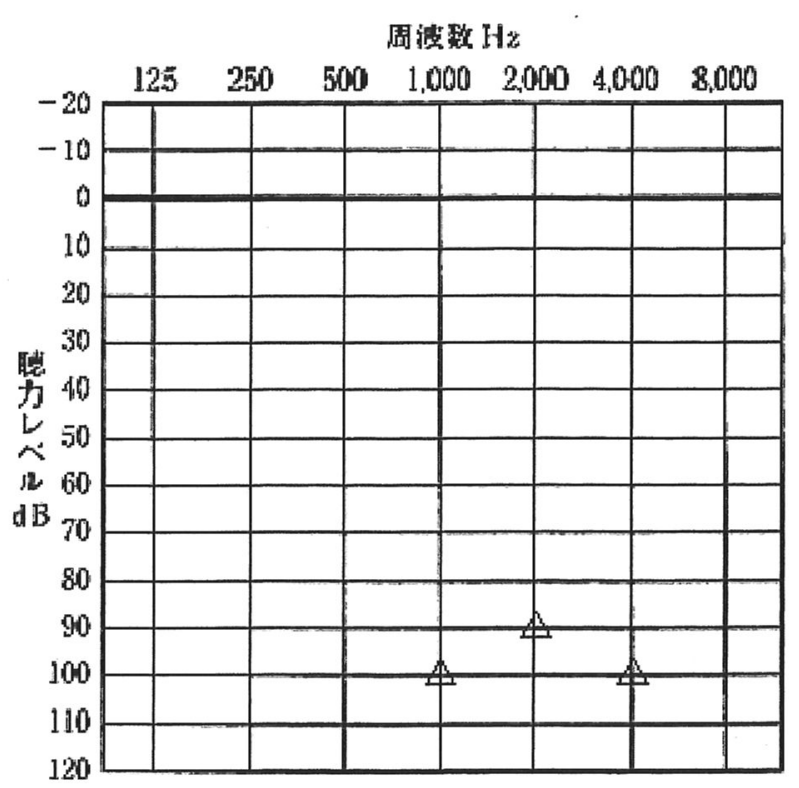

図55月 7 日に施行した CORの結果

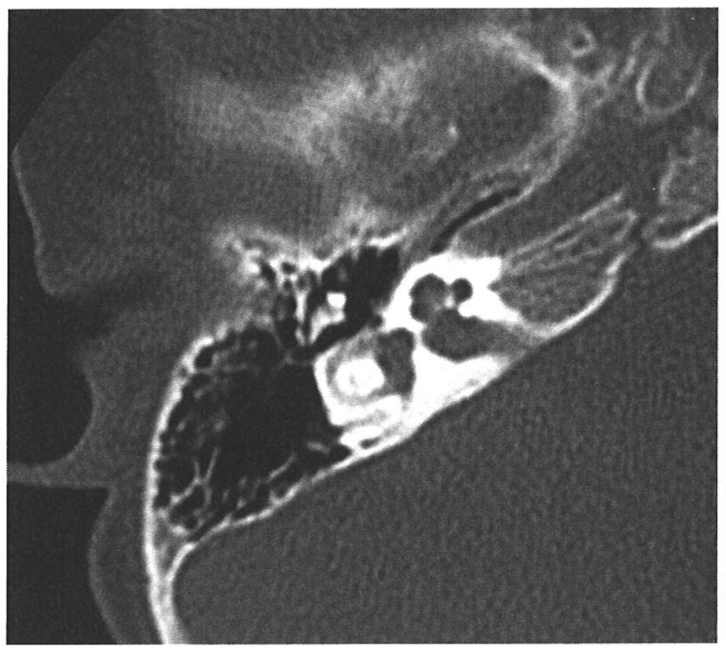

固紴敕 $\mathrm{Hz}$

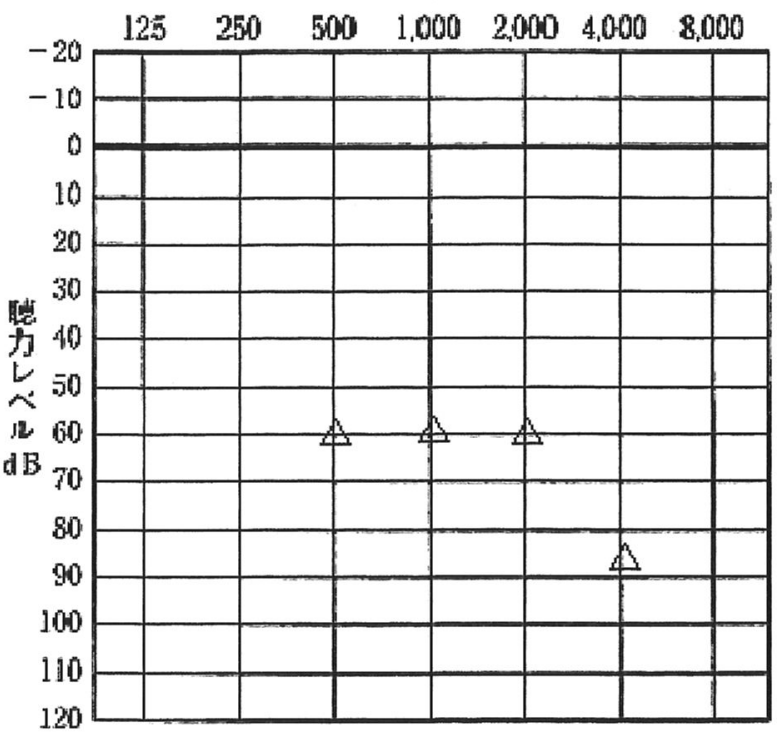

図75月24日に施行した CORの結果

図 65 月13日に施行した中耳 CT 所見

も死亡例や合併症を伴うことが決して稀れではない 疾患である。細菌性髄膜炎の合併症としての難聴は, 生存した䯣膜炎の約 4 から $30 \%$ に生じる ${ }^{1 \sim 5)}$ とされ ている。生存し得た髄膜炎後の患児にとって，難聴 は精神神経学的発育を妨げる因子であり, 社会的に も重要な問題となる。

インフルエンザ菌䯣膜炎は, 近年海外では Hib (Hemophilus influenzae type b) ワクチン導入によ り激減して ${ }^{1,6)}$ いるため, 海外ではインフルエンザ 菌が問題となることは少ない。一方，本邦では依然 としてインフルエンザ菌は䯣膜炎の最多起因菌であ り，その頻度は最近むしろ増加傾向にある年名と言

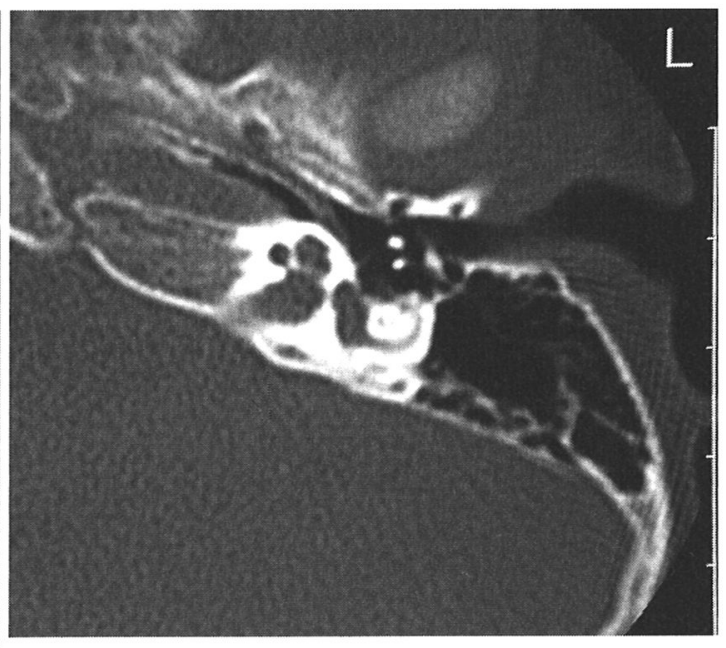

われている。また，本邦のインフルエンザ菌髄膜炎 の報告では，インフルエンザ菌の中で $30.6 \%$ low

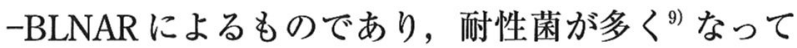
おり治療に難渋する例が多くなっている。

䯣膜炎による難聴の回復を認めたとする症例の報 告6,10 14) も散見されているが，一般的に不可逆性で あり，細菌性髄膜炎による難聴の回復は困難とされ ている。細菌性䯣膜炎の内耳炎による後遺症として 問題となるのが，内耳の骨化であり，両側高度難聴 が生じた場合に必要となる人工内耳埋め込み手術の 成績を悪化させる重要な問題である。骨化の障害が つよい原因菌として過去の報告に挙がっているもの 


\section{左耳}

$(\mathrm{dBnHL})$

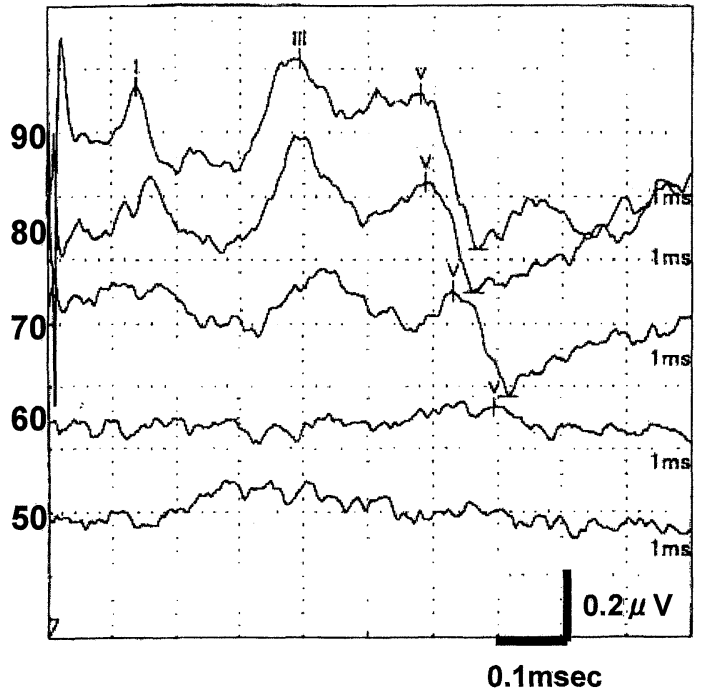

図85月27日に施行した ABR

Triclofos sodium を用い非覚醒状態で，シールドルームで施行した。

\section{右耳}

(dBnHL)

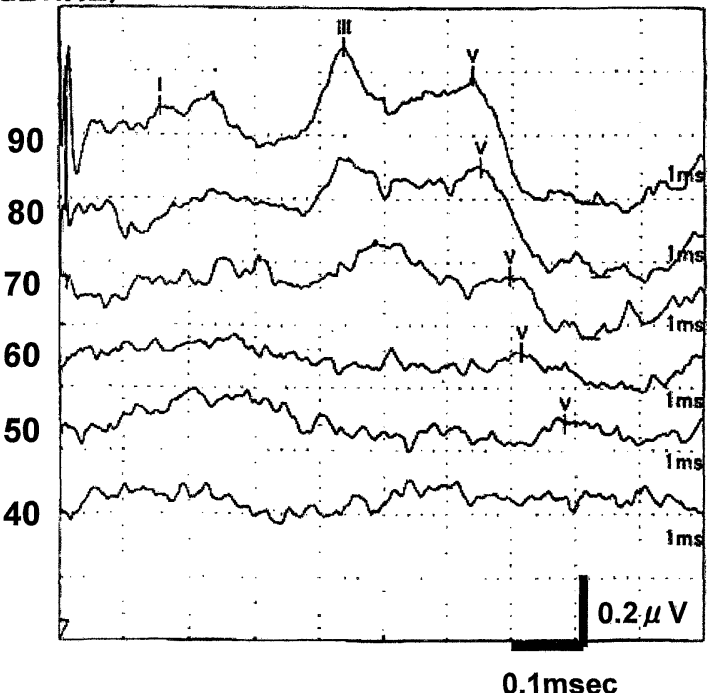

周波敕 $\mathrm{Hz}$

$\begin{array}{lllllll}125 & 250 & 500 & 1,000 & 2,000 & 4,000 & 8,000\end{array}$

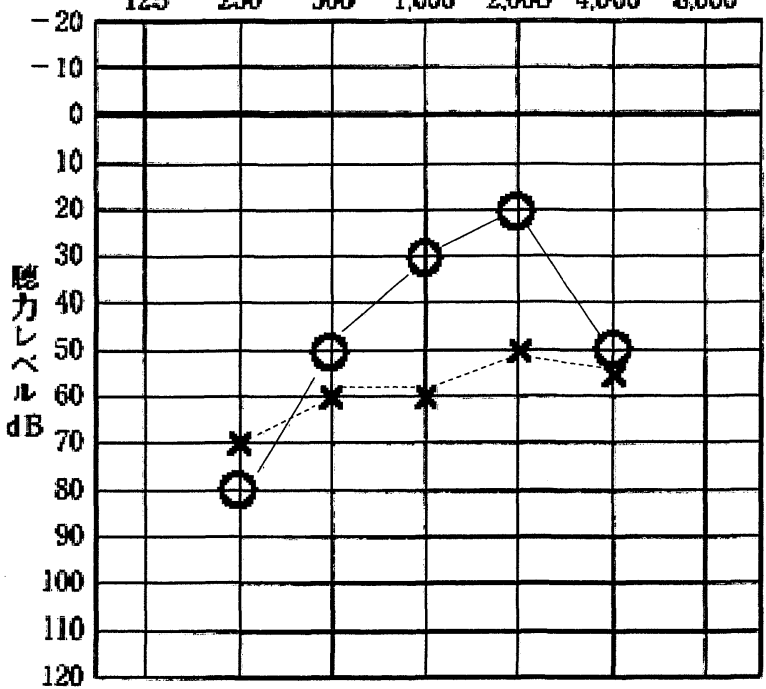

図 9 a 7 月 8 日に施行した純音聴力検査による気導閾値
では, S. pneumoniae によるものが高度で Neisseria meningitides, Heamophilus influenzae などがそれ に続く ${ }^{15,16)}$ とされいる。

髄膜炎による難聴の子予後因子として，㖪膜炎の治 療開始時期, 䯣液中の糖濃度の低値, 頭蓋内圧の上 昇, 項部硬直, S. pneumoniae の感染など,7) が報告 されている。本症例では，項部硬直や髄液中の糖濃 度の低値を認めており，聴力予後は不良となること

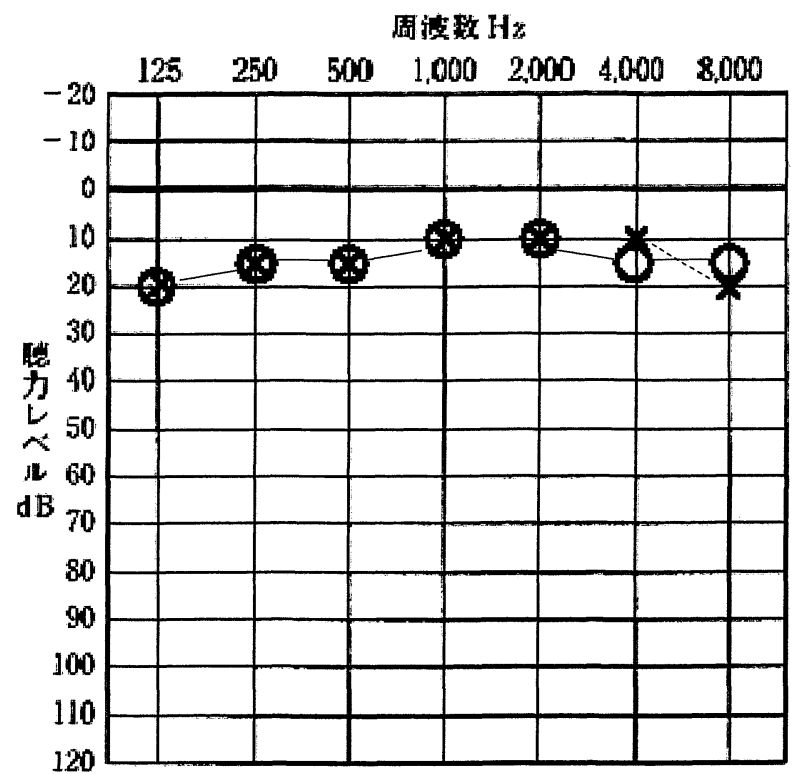

図 9b 11月18日に施行した純音聴力検查による気導閾値

が予測された。

本症例は，髄膜炎発症後24時間以内に髄膜炎の入 院治療が開始され，それに引き続きデカドロンとグ リセオールの点滴が小児科より施行された。また, 難聴を確認した後ステロイドの内服を再度追加し た。髄膜炎に対する早期のステロイド投与は，炎症 性サイトカインやその関連代謝物の産生を抑制する 働きがあり ${ }^{17)}$ ，髄液中の糖，乳酸や蛋白濃度を改善 
する18,19) とされている。また，ステロイドは蝸牛の 骨化を予防するとされ20)，また無作為盲検法による 検討で, 発症後早期 Dexamethasone 投与によって 重度の聴覚障害を軽減する効果がある ${ }^{21)}$ との報告が ある。さらに, Dexamethasone とグリセオール投 与群の聴力障害や神経脱落症状は, グリセオール非 投与群のそれに比べ，より軽症であるとの報告 ${ }^{22)} も$ ある。本症例は, 幸い初期の難聴の程度は中等度か ら高度の範囲であると推定され, 完全な聾ではなか った。このような因子が重なって, 緩徐であるが著 明な聴力改善をがみられたものと考える。

今回の内耳炎の病態については, あくまで推測で はあるが，良好な聴力改善がみられたことにより， いわゆる serous labyrinthitis の状態であったと思わ れる。有毛細胞の不可逆的な破壊を伴う suppurative labyrinthitis では，このような著明な聴力改善はみ られなかったと考えられる。

本症例の経験から改善の乏しいとされる細菌性髄 膜炎後難聴の場合でも，投与可能な全身状態であれ ば，本来の䯣膜炎の治療と併行し難聴に対しても有 用性が報告されているステロイド等の投与を行うこ とが，まず必要である。また，䯣膜炎による難聴へ の対処として早い時期に補聴器装用や人工内耳手術 などを行う場合も, 稀ではあるが聴力改善の可能性 もあることを十分に念頭においておく必要があるも のと思われた。

海外ではインフルエンザ菌に対するワクチンが導 入され予防に十分な効果をあげているが，本邦では ワクチンに対する心理的抵抗が強く, 今後もインフ ルエンザ菌に対するワクチンが本邦で定着するか否 かは, 現時点でははっきりしない。インフルエンザ 菌による髄膜炎からの内耳障害は, 耳鼻咽喉科にお ける予防医学の面からも, 重要な問題の一つである と思われた。

本論文は第50回日本聴覚医学会（平成17年）にお いてロ演した。

\section{Recovery from post-meningitic hearing loss : A case report}

Ryoji Hirai, Shuntaro Shigihara, and Minoru
Ikeda

Department of Otorhinolaryngology, Nihon University School of Medicine, Tokyo, Japan

Bacterial meningitis is one of the most common causes of acquired sensorineural hearing loss in children. We describe a 3-year-old boy with BLNAR meningitis, complicated with moderate to severe hearing loss and equilibrium disorder. He was given antibiotics, steroids, glycerol and gabexate mesylate. About a half year later, his hearing loss recovered to a completely normal level. We suggest that the inner ear damage in this case might have been due to serous labyrinthitis.

\section{参考文献}

1) Wellman MB, Sommer DD, McKenna J : Sensorineural hearing loss in postmeningitic children. Otology and Neurootogy 24 : 907-912, 2003

2 ) Schuknecht HF : Pathology of the ear : second edition, Lea and Febiger : 211-218, 1993

3 ）全 有耳, 長村敏生, 岡野創造, 他 : 1992 1997 年に経験したインフルエンザ菌性髄膜炎33例の臨 床検討。小児科臨床 55：877-885, 2002

4) Vernon $M:$ Meningitis and deafness : the problem, its physical, audiological, psychological and educational manifestations in deaf children. Laryngoscope $77:$ 1856-1874, 1967

5 ) Nadol J : Hearing loss as a sequela of meninigitis. Laryngoscope 88:739-755, 1978

6 ) Woolley AL, Kirk KA, Neumann, JR : Risk factors for hearing loss from meningitis in Children. Arch otolaryngol head neck surg $125: 509-514$, 1999

7 ) Eisenhunt M, Meehan T, Batchelor L : Cerebrospinal Fluid Glucose Levels and Sensorineural hearing loss in bacterial Meningitis.Infection 31 : 247-250, 2003

8 ）上原すぶ子, 神谷 斎, 富樫武弘, 他：わが国 の小児インフルエンザ菌髄膜炎の疫学調查成績 （1994年）一細菌性髄膜炎との対比ならびに䍜患 率一。日本小児科学会雑誌 $102: 656-665,1998$ 
9 ）塩見正司：インフルエンザ菌髄膜炎。総合臨床 53 : 1957-1962, 2004

10) Rosenhall ULF, Kankkuen A : Hearing Alterations following Meningitis Hearing Improvement : Ear and Hearing $1: 185-190,1980$

11) McCormick B, Gibbin KP, Lutman ME, et al : Late partial recovery from meningitic deafness after cochlear implantation. The American Journal of otology 14:610-612, 1993

12) Marx RD, Bear ST: Spontaneous recovery of profound post-meningitic hearing loss. The journal of Laryngology \& Otology 115 : 412-414, 2001

13）小形 章, 犬山里代, 増田正純, 他: ABR 所 見で回復を示した髄膜炎後難聴の一例。Otol Jpn 6 : 522,1996

14）成尾一彦, 西村忠巳, 岡本英之, 他：聴力改善 がみられた化膿性䯤膜炎の一症例。Audiology Japan $43: 453-454,2000$

15) Dodge PR, Davis H, Feigin RD, et al : Prospective evaluation of hearing impairment as a sequela of acute bacterial meningitis. N Engl J Med 311 : 864-874, 1984

16) Axon PR, Templa RH, Saeed SR, et al : Cochlear ossification after meninigitis. Am J Otol 19 : 724729, 1998

17）竹下幹彦, 川俣喜一, 糟谷英俊 : 髄膜炎の補助 療法一ステロイドは有効か。化学療法の領域 17 : 1244-1249, 2001

18) Syrigiannopoulos GA, Olsen KD, Reisch JS, et al : Dexamethasone in the treatment of expermen- tal Haemophilus influenzae type B meningitis. J Infect Dis 155 : 213-219, 1987

19) Mustafa MM, Ramilo O, Mertsola J, et al: Modulation of inflammation and cachectin activity in relation to treatment of experimental Hemophilus influenze type $B$ meningitis. $J$ infect Dis 160 : 818-825, 1989

20) Hartnick CJ, Kim HH, Chute PM, et al : Preventing labyrinthitis ossificans: The Role of Steroids. Arch otolaryngol head neck surg $127: 180-183$, 2001

21) McIntyre PB, Berkey CS, King SM, et al: Dexmethasone as adjunctive therapy in bacterial meningitis : A meta-analysis of randomized clinical trials since 1988. JAMA 278 : 925-931, 1997

22) Kilpi T, Peltola H, Jauhiainen T, et al : Oral glycerol and intravenous dexamethasone in preventing neurologic and audiologic sequelae of childhood bacterial meningitis. The Finnish study group. Pediatr Infect Dis J 14：270-278, 1995

（原稿受付 平成19.4.19）

別冊請求先 $\overline{1} 173-8610$ 東京都板橋区大谷口上町 30-1

日本大学医学部耳鼻咽㑨科

平井 良治

\section{Reprint request :}

30-1 Oyaguchi Kamimachi, Itabashi-ku, Tokyo 1738610, Japan 